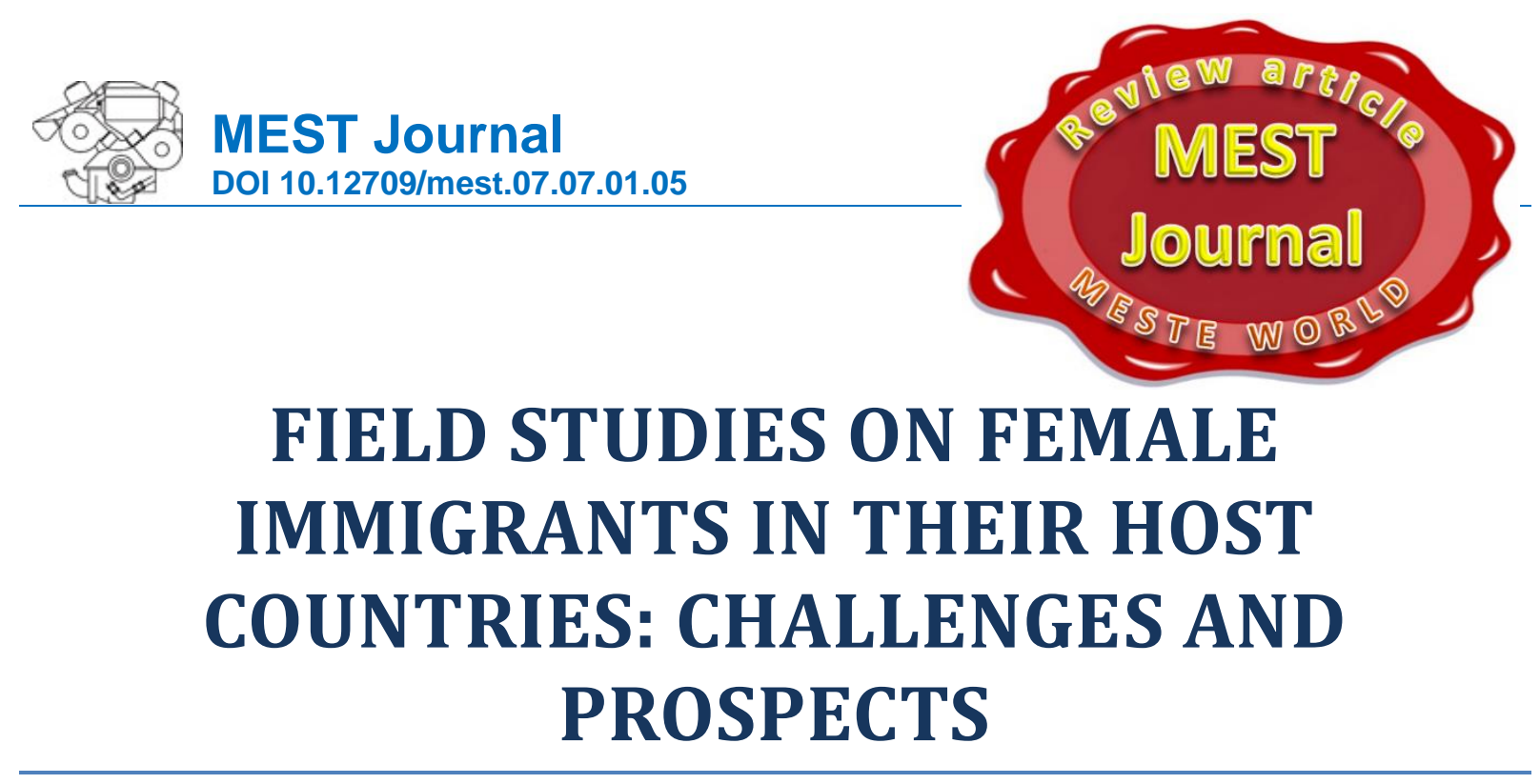

\title{
Oksana Koshulko
}

Graduate School for Social Research of the Institute of Philosophy and Sociology of the Polish Academy of Sciences, Warsaw, Poland

CMESTE

JEL Category: F2, F22, J6, J61, R2, R23

\begin{abstract}
This paper presents the results of field studies concerning female immigration in Turkey, mainly Istanbul, conducted in Turkey in the 2014-2015 academic year. Objectives of field studies were: identification of female immigrants' reasons for coming to Turkey in recent years; determination of the differences and similarities for their migration, estimation of their issues, prospects, and challenges in Turkey and the consequences of their migration. The results of these field studies showed similarities in their reasons for migration to Turkey. The main reason was their desire to start a new life in that country. The immigrants came to Turkey for various reasons - to marry, to study, to find a business and for other reasons. In these cases, their former life has finished, and they start a new page in their life in the new country. Differences in the migration to Turkey were their characters, the manner of their migration and their level of culture and education. The results of the field studies show the main prospects for them may be marriage using this as a "social elevator", which "refers to moving from the very bottom of a society to its top". The biggest challenges for female migrants in Turkey may be unemployment; access to quality health services and retirement pension provision; language barrier; violence and abuse in families and in the society; and gender inequality in the country.
\end{abstract}

Keywords: field studies, female immigration, host country, direct observation, face-to-face interviews, surveys, issues, prospects, challenges, and consequences

\section{INTRODUCTION}

The research presents the results of field studies on female immigration in Turkey, mainly in Istanbul, conducted in Turkey in the 2014-2015

Address of the author:

Oksana Koshulko

拝=" oksanakoshulko2015@gmail.com academic year, thanks to the financial support of the Scientific \& Technological Research Council of Turkey (TUBITAK).

Data presented in the article was collected mainly in Istanbul using face-to-face interviews, surveys, and direct observation among female immigrants from various countries. Objectives of field studies were to identify the various reasons for female migrants coming to Turkey in recent years; to 
determine differences and similarities in their migration to the country; and to estimate their issues, prospects, challenges, and consequences from the process of migration.

\section{METHODOLOGY AND STRATEGY OF FIELD STUDIES}

According to data of Chevette Alston (2018), "field studies involve collecting data outside of an experimental or lab setting.

This type of data collection is most often done in natural settings or environments and can be done in a variety of ways for various disciplines. Field studies are known to be expensive and timely; however, the amount and diversity of the data collected can be invaluable.

Field studies collect original or unconventional data via face-to-face interviews, surveys, or direct observation. This research technique is usually treated as an initial form of research because the data collected is specific only to the purpose for which it was gathered. Therefore, it is not applicable to the general public."

According to data from Chevette Alston (2018), "field studies should be carefully planned and prepared to ensure that the data collected is accurate, valid, and collected efficiently. The equipment needed will depend on the type of study being conducted.

The process first starts by clearly stating the problem and defining the area of study. From there, a hypothesis, or a theory of explanation, is set forth to explain any occurrences expected for the specified group."

The field studies in Turkey, mainly in Istanbul, consisted of face-to-face interviews, surveys, and direct observation.

The snowball sampling method was very useful and using this method some female immigrants helped to find other immigrants for the interviews and surveys in Turkey.

The strategy of the research consisted of the following stages: collecting data through surveys and semi-structured interviews among female immigrants in Turkey; creating a database using the responses; the statistical and numerical analysis of received data.

\section{OBJECTIVES OF FIELD STUDIES}

Objectives of Field Studies were:

- To identify the various reasons why female immigrants have come to Turkey in recent years;

- To determine differences and similarities in the processes of migration of women to Turkey;

- To estimate issues, prospects, challenges, and consequences of female migrants coming to Turkey.

\section{PREVIOUS RESEARCH IN THE AREA}

This subject is a very topical and many scientists worldwide have studied Female Migration, among them Ibrahim Sirkeci and Jeffrey H. Cohen (2016), Kalervo Oberg (1960), Rachel Irwin (2007), Nicola Piper and Amber French (2011), and many others.

This paper is the continuation of a series of publications concerning Labor, International, and Female immigration abroad in recent years and among these publications are the papers "Human capital depreciation of female immigrants and ways to restore lost human capital"; "Children of female immigrants in Turkey: numerical analysis of data"; "Research into the dilemmas concerning the employment of immigrants in their professions abroad and the depreciation or restoration of their human capital"; "Slavic women in Turkey: from past to present"; Challenges of Ukrainian female immigrants and their children in host countries"; Women from North move to South: Contemporary migration from the Former Soviet Union countries to Turkey; Discourse about Women-Immigrants from Former Soviet Union Countries as a Special Social Group in Turkey"; "The role of Ukrainians in the economic growth of Poland"; "Gender inequality as one of the largest problems of Slavic women in Islamic world"; "Reflections on the features of accumulation of the Human Capital of representatives of female and male genders"; "Ukrainians in the Light of Migration Crisis in Europe"; "Exploring of the Human Capital Depreciation of Ukrainian Labor Migrants Abroad: Results of a Survey"; "Issues in countries of the former Soviet Union as the driving force for female migration to Turkey"; "The "Value of Life and Labor" of Ukrainian Migrants Abroad"; "The 
positive and negative aspects of Ukrainian labor migration for Ukraine and Receiving Countries" (Koshulko, 2015-2018).

\section{FIELD STUDIES DIFFERENCES FOR
IMMIGRANTS FEMALE}

The results of the research show that the differences in the processes of migration of female immigrants to Turkey were in the characters of these immigrants, in their reasons for migrating and in their level of culture and education.

This process is very personal because each person views the process of migration differently. Some intend to marry and have children, which for them is enough. For others, the most important factor was their career, or business, in their new country.

There are also differences in the causes of female migration to Turkey. Some are escaping the poverty and employment in their own country. The second group of female migrants came to Turkey to escape the wars and revolutions in their own countries and, the third group is escaping difficult relationships within families at home.

There are also differences in the nationalities and ethnic groups of female immigrants. Participants of this study were female migrants of 27 nationalities and ethnic groups, coming from 15 countries. Ten, or $37 \%$, of these nationalities and ethnic groups, belong to the Turkic people and, of course, female migrants, belonging to the Turkic people, may adopt more easily in Turkey than female immigrants of other nationalities and ethnic groups.

Another difference is an unwillingness to convert to another religion. Some female immigrants feel able to convert to Islam, which brings them benefits in Turkish families and the wider society. However, some female immigrants feel unable to convert into any situation and some have even become apostates after having once converted to Islam.

These differences are obstacles to be overcome by female immigrants to Turkey. Some of the immigrants study the Turkish language and culture at universities and take courses in Turkish with the aim of going to Turkey, staying there officially and working as professionals. Others go to Turkey to improve their lives in other ways.

There are differences between female migrants in the areas of lifestyle, behavior in their home country and the different types of lives they wish to lead in Turkey.

\section{FIELD STUDIES OF SIMILARITIES OF FEMALE IMMIGRANTS IN THE PROCESSES OF MIGRATION}

Similarities among the immigrants to Turkey are in their desire to start a new life there. The immigrants came to Turkey for many reasons - to marry, to study, to start a business and for other reasons. In all these cases, their former life has finished, and they are starting a new page in the story of their life.

All of them pass through the stages of adaptation in the new country. According to data from Kalervo Oberg in his book "Culture Shock: Adjustment to New Cultural Environments" (1960), all the immigrants go through distinct phases: Honeymoon, Crisis, Recovery, and Adjustment.

According to data from Rachel Irwin in her article 'Culture shock: negotiating feelings in the field', "...Culture shock is the depression and anxiety experienced by many people when they travel or move to a new social and cultural setting" (Irwin, 2007). Therefore, culture shock is an experience shared by all the immigrants in their new country and it is very important for them to receive support and help from their husbands and other relatives.

The next similarity among immigrants is the necessity of accepting some general rules in Islamic Sharia if they decide to marry Turkish men. In this case, the immigrants, who are non-Muslim women, need to accept the following rules of Islamic Sharia (Sawma, 2013):

- Women need to accept the fact that children born from marriages with Muslim men are always considered Muslims;

- Women need to accept that under the rules of Islamic Sharia; male children must be circumcised, which is standard practice among Muslims;

- Women need to know that in the event of divorce or death of the husband Islamic Sharia decrees that in mixed marriages where the 
husband is Muslim, and the wife is not, the wife will lose custody of the children;

- Women need to accept that wives of Muslim men cannot travel with their children without the permission of their husbands;

- Women need to know that in a situation of inheritance, under the general rule in Islamic Sharia, women inherit only half the amount that men who have the same degree of relation to the deceased.

\section{FIELD STUDIES OF ISSUES OF WOMEN FROM DIFFERENT COUNTRIES, ARISING FROM MIGRATION}

The areas that may be affected by issues arising from migration from different countries are issues for the women themselves returning their home countries after a period of time spent in another country (return migration); and issues for these home countries, which affected by the outflows of female emigrants.

Each of these issues may arise for women migrating from their countries of origin to Turkey: issues for female immigrants in Turkey may be manifested in different forms of discrimination in the host society. Nicola Piper and Amber French (2011) wrote that female migrants in their host country face dual discriminations because they are women and they are non-citizens there: "Indeed, gender-based inequalities, injustice, discrimination, and outright violence continue to permeate all societies to a certain extent, in some form or another. Such outcomes are often brought to the surface through or are the result of, the migrant experience which, for women, typically means dual discrimination on the basis of being female and a non-citizen or absent citizen. Yet migration may allow women to turn these negative outcomes around by gaining greater control of their lives, whether through escape from traditional gender roles, improved knowledge, and awareness about their rights, or newfound financial independence. Whether they migrate between two societies with opposing or comparable human development situations, women may find that they are liberated simply by having taken on a new role because of the move" (Piper, 2011).
Issues, arising for the female migrants if they are unhappy with their husbands and/or their Turkish relatives may be manifested by negative reactions if they find they cannot change their lives or return to their home country. If they do not have opportunities and second changes in their lives, they may lose all motivation to live.

\section{FIELD STUDIES OF PROSPECTS AND CHALLENGES OF FEMALE IMMIGRANTS IN TURKEY}

According to the results of field studies on female immigration in Turkey, the main prospect for female immigrants in Turkey is to marry good Turkish men using the "social elevator". Pitirim Sorokin has explained in his book "Social mobility" that "social elevator" "refers to moving from the very bottom of a society to its top' (Sorokin, 1998). The results of field studies on female immigration in Turkey show that many female immigrants have high expectations that a "social elevator," brought about by marriage, will change their lives for the better in their new country.

The biggest challenges for female immigrants in Turkey may be unemployment; access to quality health services and retirement pension provision; the language barrier; violence and abuse within families and in Turkish society; and gender inequality in the country.

There is little chance for the women to would like to stay in their professions in the host country, or at least they have a long and a difficult road to travel to achieve this. First, they must have the consent of their husbands to work but the majority of men do not want to see their wives employed. Second, they need to study Turkish and become fluent. Third, they need to follow the procedure top gain recognition of their academic diplomas in Turkey. This procedure may take years and only a few women are able to complete it successfully.

Consequences of migration to Turkey may arise for the immigrants returning to their countries of origin after failed migration as well as for the countries of origin of the immigrants.

Consequences for the immigrants in Turkey may be manifested by various forms of discrimination; by alcoholism or other negative reactions if the immigrants cannot change their lives or return to their home countries; or by consequences for the 
children and grandchildren of the immigrants. The migrants may return to their countries of origin after being away for various reasons, divorces, deportation etc. These situations can be complicated when the immigrants are forced to leave their children in Turkey.

Consequences for the home countries of the migrants may result in an increase in an aging population and negative population growth for many of the countries of origin of the immigrants.

\section{CONCLUSIONS}

The results of field studies on female immigration in Turkey show that female migration to that country may arise due to poverty, unemployment, low standards of living, lack of prospects in their home countries.

The majority of the immigrants think that migration and marriage to foreigners they can solve all or the majority of their material and financial problems but in fact they face many problems abroad, such as discrimination, violence, lack of understanding and respect, language barrier, lack of opportunities to work and to build a career, etc.

Most of the immigrants, who would like to stay permanently in Turkey, need to start learning how to survive in a different culture, with different traditions and religion, because international couples who have married are two different people and, if they do not speak a common language, they may very well find that they have different views on their future life.

Female immigrants may have similar issues in Turkey with difficulties in learning Turkish, adapting to a different culture and traditions and achieving integration.
It is very hard for those who would like to stay in their professions in Turkey as they have to undergo a long and difficult process to achieve this. First, they must have the consent of their husbands to work but the majority of men do not want to see their wives employed. Second, they need to study Turkish and become fluent. Third, they need to undergo the procedure of gaining recognition for their academic diplomas in Turkey. This procedure may take years and very few women complete it successfully.

The results of field studies on female immigration in Turkey show that the main prospect for female immigrants in Turkey may be to get married to some good Turkish men and using the "social elevator" that "refers to moving from the very bottom of a society to its top".

The biggest challenges for female immigrants in Turkey may be unemployment; access to quality health services and retirement pension provision; the language barrier; violence and abuse within their families and in Turkish society; and gender inequality in the country.

Consequences for the immigrants in the host country manifest themselves by various forms of discrimination in the host society; in alcoholism or other negative reactions if the women cannot change their lives or return to their home countries; or in consequences for their children and grandchildren. Consequences for the immigrants returning to their home countries after being away might be divorces, deportation etc. These situations may be more complicated when the women are forced to leave their children in Turkey.

\section{WORKS CITED}

Alston, C. (2018). Field Study: Definition \& Research. Related Study Materials. Study.com. Accessed 14 Feb 2018. https://study.com/academy/lesson/field-study-definition-research-quiz.html.

Irwin, R. (2007). Culture shock: negotiating feelings in the field. Anthropology Matters. Vol 9, No 1 (2007) Accessed 14 Feb 2018. http://www.anthropologymatters.com/index.php/anth_matters/article/view/64/123.

Koshulko, O. (2018). Human capital depreciation of female immigrants and ways to restore lost human capital. MEST Journal, 15 Jan, Vol. 6(1), pp. 27-33, Belgrade, Serbia.

Koshulko O. (2017). Children of female immigrants in Turkey: numerical analysis of data. International Scientific Journal World Scientific News, 90, pp. 88-100, Nov. 2017, Katowice, Poland. 
Koshulko, O. (2017). Research into the dilemmas concerning the employment of immigrants in their professions abroad and the depreciation or restoration of their human capital. Proceedings of the 3rd International Scientific Conference "Dilemmas of scientific research in various fields of science: natural sciences, science, and technology, economic and social sciences, humanistic sciences," Katowice Institute of Information Technologies, International Scientific Journal 'World Scientific News', 89, 8-15. Katowice, Poland, November 24.

Koshulko, O. (2017, February 17-19). Slavic women in Turkey: from past to present. Proceedings of the 7th International Symposium "Gecmisten Gunumuze Goc - Migration from Past to Present," organized by Canik Municipality together with History Studies Journal, (pp. 2117-2124), Canik, Samsun, Turkey.

Koshulko, O., \& Kobets, V. (2017, April 25-26). Challenges of Ukrainian female immigrants and their children in host countries. Proceedings of the $9^{\text {th }}$ Junior Researchers Conference on the European and National context in research, Polotsk State University, (pp. 110-113), Novopolotsk, Belarus.

Koshulko, O. (2016). Women from North move to South: Contemporary migration from the Former Soviet Union countries to Turkey. Transnational Press London Ltd., UK, 126 p.

Koshulko, O. (2016). Discourse about Women-Immigrants from Former Soviet Union Countries as a Special Social Group in Turkey. In: Gender in Transnational Societies: Feminist Scholarship and Personal Narratives by RujutaChincholkar-Mandelia and MoiyattuBanya, pp. 165-167, Cognella Academic Publishing, San Diego, USA.

Koshulko, O., \& Koshulko V. (2016, Feb.). The role of Ukrainians in the economic growth of Poland. An International Research On-line Journal Scientific News, 42, pp. 256-266. Poland. EISSN: 2392-2192.

Koshulko, O. (2016, October 27-28). Gender inequality as one of the largest problems of Slavic women in the Islamic world. Proceedings of the $6^{\text {th }}$ International conference "Gender and communicative behavior," Polotsk State University, Polotsk, Republic of Belarus.

Koshulko, O. (2016, October 20-21). Reflections on the features of accumulation of the Human Capital of representatives of female and male genders. Proceedings of the II International Scientific Conference "Economic Theory of the XXI century: Search for Effective Mechanisms of Economic Management," Polotsk State University (pp. 78-81), Polotsk, Republic of Belarus.

Koshulko, O. (2016, May 30-31). Ukrainians in the Light of Migration Crisis in Europe. Proceedings of the International Workshop "Human rights - contemporary threats and challenges", Faculty of Law, Administration and Economics, University of Wroclaw, Wroclaw, Poland.

Koshulko, O. (2015, Nov.). Exploring the Human Capital Depreciation of Ukrainian Labor Migrants Abroad: Results of a Survey. International Letters of Social and Humanistic Sciences, 64, pp. 66-72. SciPress Ltd., Switzerland doi: 10.18052/www.scipress.com/ILSHS.64.66.

Koshulko, O., \& Onkal, G. (2015). Issues in countries of the former Soviet Union as the driving force for female migration to Turkey. International Letters of Social and Humanistic Sciences, 56, 120126. Online: 2015-07-17. SciPress Ltd., Switzerland doi: 10.18052/www.scipress.com/ILSHS.56.120.

Koshulko, O. (2015, Sep.). The "Value of Life and Labor" of Ukrainian Migrants Abroad. International Letters of Social and Humanistic Sciences, 59, 1-8, SciPress Ltd., Switzerland doi: 10.18052/www.scipress.com/ILSHS.59.1.

Koshulko, O. (2015, November 20-21). The positive and negative aspects of Ukrainian labor migration for Ukraine and Receiving Countries. Proceedings of the 10th International Conference of the Albanian Institute of Sociology (AIS) "How the International Migration is shaping the 
Contemporary Society?" / Edited by Elda Sokoli Kutrolli, Naile Demiri. AAB College (pp. 1718), Prishtina, .

Oberg, K. (1960). Culture Shock: Adjustment to New Cultural Environments. Practical Anthropology, 7, 177-182.

Piper, N., \& French, A. (2011). Do Women Benefit from Migration? An Editorial Introduction. Special issue 'Female Migration Outcomes: Human Rights Perspectives'. Diversities, 13(1), 1-3. Accessed 14 Feb 2018. http://www.mmg.mpg.de/subsites/diversities/past-issues/femalemigration-outcomes/editorial-introduction-do-women-benefit-from-migration/.

Sawma, G. (2013). Muslim Men Marrying Non-Muslim Women. International Law. Accessed 14 Feb 2018. http://gabrielsawma.blogspot.com/2013/07/muslim-men-marrying-non-muslimwomen_5.html.

Sirkeci, I., \& Cohen, J.H. (2016). Cultures of migration and conflict in contemporary human mobility in Turkey. European Review, 24(3), 381-396.

Sorokin, P. (1998). Social mobility. London: Routledge / Thoemmes Press, 559 p.

Received for publication: 04.03.2018

Revision received: $\quad 28.08 .2018$

Accepted for publication: 27.12.2018

\section{How to cite this article?}

Style - APA Sixth Edition:

Koshulko, O. (2019, January 15). Field Studies on Female Immigrants in Their Host Countries: Challenges and Prospects. (Z. Čekerevac, Ed.) MEST Journal, 7(1), 34-40. doi:10.12709/mest.07.07.01.05

Style - Chicago Sixteenth Edition:

Koshulko, Oksana. 2019. "Field Studies on Female Immigrants in Their Host Countries: Challenges and Prospects." Edited by Zoran Čekerevac. MEST Journal (MESTE) 7 (1): 34-40. doi:10.12709/mest.07.07.01.05.

Style - GOST Name Sort:

Koshulko Oksana Field Studies on Female Immigrants in Their Host Countries: Challenges and Prospects [Journal] // MEST Journal / ed. Čekerevac Zoran. - Belgrade - Toronto : MESTE, January 15, 2019. - 1 : Vol. 7. - pp. 34-40. doi:10.12709/mest.07.07.01.05

Style - Harvard Anglia:

Koshulko, O., 2019. Field Studies on Female Immigrants in Their Host Countries: Challenges and Prospects. MEST Journal, 15 January, 7(1), pp. 34-40.

Style - ISO 690 Numerical Reference:

Field Studies on Female Immigrants in Their Host Countries: Challenges and Prospects. Koshulko, Oksana. [ed.] Zoran Čekerevac. 1, Belgrade - Toronto : MESTE, January 15, 2019, MEST Journal, Vol. 7, pp. 34-40. 